\title{
Analiza numeryczna zgrzewania rezystancyjnego prętów na krzyż przy pneumatycznym i serwomechanicznym docisku elektrod - model 3D
}

\author{
Analysis of Resistance Cross Wire Welding \\ with Pneumatic and Servomechanical Electrode Force \\ - FEM Calculations and 3D Model
}

\section{Streszczenie}

W artykule przeanalizowano proces zgrzewania rezystancyjnego prętów ze stopów aluminium w konfiguracji na krzyż przy pneumatycznym oraz serwomechanicznym docisku elektrod zgrzewarki. Analiza prowadzona była numerycznie z wykorzystaniem oprogramowania SORPAS - model 3D. Obliczenia prowadzono dla aluminium gatunku AA5182 i średnicy prętów $4 \mathrm{~mm}$. Dla systemu pneumatycznego docisku analiza prowadzona była dla różnych wartości prądów zgrzewania i siły docisku. Analizowano następujące wielkości: przemieszczenie elektrod, rezystancję zastępczą statyczną obszaru zgrzewania, przestrzenny rozkład mocy zgrzewania, energię dostarczoną do zgrzeiny, średnicę jądra zgrzeiny oraz objętość roztopionego metalu. Obliczenia prowadzono aż do osiągniecia jednego z przyjętych warunków granicznych tj., np. maksymalnego czasu zgrzewania (63 ms), maksymalnego przenikania prętów (20\%), wyprysku ciekłego metalu. Badania ukierunkowane były na optymalizację procesu zgrzewania poprzez zastosowanie systemu serwomechnicznego i odpowiedniego sterowania siłą docisku lub/i przemieszczeniem elektrod. W wyniku uzyskiwany jest korzystniejszy przestrzenny rozkład mocy zgrzewania, w którym energia koncentrowana jest w centralnej strefie zgrzeiny. Dla systemu pneumatycznego docisku nie jest możliwe uzyskanie założonej nominalnej średnicy jądra zgrzeiny (> 1,9 mm) i obserwowane jest tworzenie zgrzeiny pierścieniowej w całym zakresie parametrów zgrzewania. Dla systemu serwomechanicznego obserwowane jest natomiast przetopienie materiału w całym obszarze zgrzeiny i uzyskiwane jest pełne jądro o nominalnej założonej średnicy. Do analizy wyników obliczeń MES i graficznej prezentacji zastosowano oprogramowanie STATISTICA.

Słowa kluczowe: zgrzewanie rezystancyjne; pneumatyczny system; serwomechaniczny i elektromechaniczny system docisku elektrod zgrzewarki; zgrzewanie prętów na krzyż
Abstract

The article analyses the resistance cross wire welding of aluminium bars using the pneumatic and servomechanical force of welding machine electrodes. The analysis was performed in a numerical manner using the SORPAS software programme (model 3D). The calculations were performed for bars made of aluminium AA5182 and having a diameter of $4 \mathrm{~mm}$. In terms of the pneumatic system, the analysis was performed for various values of welding current and electrode force. In addition, the analysis also involved such quantities as electrode travel, the static slope resistance of the welding area, the space distribution of welding power, energy supplied to the weld, the weld nugget diameter and the volume of metal. The calculations were conducted until one of the adopted boundary conditions, i.e. the maximum welding time (63 $\mathrm{ms}$ ), the maximum penetration of bars $(20 \%)$ or the expulsion of liquid metal was reached. The tests aimed to optimise the welding process by using the servomechanical electrode force system and the appropriate control of electrode force and/or travel. The tests enabled the obtainment of more convenient welding power space distribution where energy was concentrated in the central zone of the weld. As regards the pneumatic electrode force system, it was not possible to obtain the assumed nominal weld nugget diameter (> $1.9 \mathrm{~mm})$. Instead, the ring weld was formed within the entire range of welding parameters. In terms of the servomechanical force system, the material was melted in the entire weld area and the complete weld nugget having the assumed diameter was obtained. The FEM calculation results were analysed and presented graphically using the STATISTICA software programme.

Keywords: resistance welding; pneumatic/servomechanical (electromechanical) electrode force system; cross wire welding

Dr inż. Zygmunt Mikno - Instytut Spawalnictwa Gliwice.

Autor korespondencyjny/Corresponding author. zygmunt.mikno@is.gliwice.pl 


\section{Wprowadzenie}

Przebieg siły docisku, razem z przebiegiem czasowym prądu zgrzewania, jest jednym z dwóch podstawowych parametrów procesu zgrzewania rezystancyjnego. W czasie procesu zgrzewania garbowego prętów na krzyż, szczególnie dla materiałów o wysokim przewodnictwie cieplnym i elektrycznym trudno jest uzyskać pełne jądro zgrzeiny o założonej średnicy. System pneumatyczny charakteryzuje się dużą inercją mechaniczną, dlatego nie może być stosowany do szybkich zmian siły docisku. Z tego powodu, jak również z uwagi na krótkie czasy zgrzewania stopów aluminium, siła docisku ma stałą, niekorzystnie zbyt dużą wartość.

Dla dużej wartości siły docisku obserwowane są deformacje elementów zgrzewanych, natomiast dla zbyt małych wartości, obserwowane są wypryski ciekłego metalu oraz inne niezgodności np. nadtopienia materiałów zgrzewanych w obszarze kontaktu z elektrodami.

Dla pneumatycznego systemu docisku siła wywierana na elementy zgrzewane jest wynikiem ciśnienia sprężonego powietrza w cylindrze siłownika zgrzewarki. Przemieszczenie elektrod jest wynikiem działania tej siły i dodatkowo mechanicznego oporu zgrzewanych elementów.

Alternatywnym rozwiązaniem jest zastosowanie odmiennego (nowego) sposobu wywierania siły [1 $\div 6]$.

W publikacji [1] autorzy podkreślają rosnącą popularność systemu serwomechnicznego i zaletę w postaci zwiększenia szybkości ruchu elektrod podczas zgrzewania. W [2] stwierdzono możliwość poszerzenia okna parametrów technologicznych, co wpływa na poprawę zgrzewalności materiałów. W [3] podkreślono możliwości modulacji siły docisku i jej szybkich zmian, szczególnie pod koniec procesu zgrzewania. Gould [4] podkreśla wzrost trwałości elektrod w zgrzewaniu punktowym oraz zastosowanie silników serwo w technologii nitowania (ang. riveting). W pracach [5] i [6] stwierdzono, że system serwomechaniczny eliminuje dynamiczne uderzenia elektrod w materiał zgrzewany w czasie docisku wstępnego, które są charakterystyczne dla siłowników pneumatycznych. Serwomechaniczny docisk pozwala na łagodne zetknięcie elektrody z powierzchnią materiału zgrzewanego. W [6] wymieniono również inne zalety takie jak:

- szybsze operowanie zgrzewadłem serwo w przestrzeni roboczej,

- większą powtarzalność siły docisku,

- zredukowane natężenie hałasu,

- krótszy czas procesu zgrzewania,

- mniejszy ruch przy zamykaniu i otwieraniu elektrod,

co pozwala na zwiększenie trwałości mechanizmów zgrzewarki.

W nowym rozwiązaniu opisanym w niniejszym artykule, dotyczącym serwomechnicznego docisku elektrod, przemieszczenie elektrod jest parametrem zadanym a wynikiem jest siła docisku, która zależy od zadanej wartości przemieszczenia oraz od oporu mechanicznego zgrzewanych materiałów. W dostępnej literaturze autor nie natknął się na informacje dotyczące sterowania przemieszczeniem elektrod takie jak opisano w niniejszym artykule.

Autorzy artykułów [7:9] opisują nowy sposób sterowania, którego efekty są szczególnie zauważalne dla zgrzewania garbowego. W publikacji [10] opisano nowy sposób sterowania (ruchem elektrod) a w [11] sposób poprawy jakości (uzyskanie pełnego jądra) dla zgrzewania blach z wytłoczonymi garbami. Kolejna aplikacja nowego rozwiązania tj. zgrzewania prętów na krzyż została fragmentarycznie przedstawiona $\mathrm{w}$ [12].

W artykułach [10] i [11] zaprezentowano nowe rozwiązanie, w którym spowolnione jest przemieszczenie elektrod w procesie zgrzewania blach z wytłoczonym garbem.
Takie podejście do zagadnienia jest całkowicie nowe i charakteryzuje się wieloma zaletami. Nowy sposób sterowania można również zastosować do innych rodzajów zgrzewania (garbowego) np. zgrzewania prętów na krzyż. Możliwe jest zredukowanie stopnia wzajemnego przenikania prętów, wygenerowanie większej energii w pożądanym miejscu tj. na styku elementów zgrzewanych.

Nowa metoda sterowania przemieszczeniem elektrod, zaproponowana w niniejszym artykule w istotny sposób zmienia utarte poglądy w aspekcie zgrzewania rezystancyjnego, szczególnie zgrzewania prętów aluminiowych na krzyż i znacząco wpływa na rozwój badań w tym zakresie.

W artykule opisuje się część badań, które stanowią fragment większej całości, w których proces zgrzewania analizowany jest pod kątem sterowania ruchem elektrod. Nowy sposób sterowania procesem zgrzewania realizowany jest w wyniku zastosowania systemu serwomechanicznego. Badania przeprowadzone i opisane w bieżącej publikacji skupione są na obliczeniach numerycznych MES model 3D (SORPAS).

\section{Obliczenia MES}

Do obliczeń numerycznych zastosowano oprogramowania SORPAS model 3D [13], które realizuje sprzężone analizy termiczne, elektryczne, mechaniczne i metalurgiczne. Oprogramowanie posiada specjalizowany moduł obliczeniowy, który pozwala na kompleksową analizę nowego zagadnienia, jakim jest serwomechaniczny docisk elektrod. Model 3D zastosowano z uwagi na potrzebę bardzo dokładnego odwzorowania procesu zgrzewania zarówno w modelu, jak i w obliczeniach.

Złącze zgrzewanie garbowo w konfiguracji prętów na krzyż, przy zastosowaniu pneumatycznego docisku elektrod, charakteryzuje się cienką warstwą roztopionego materiału zgrzewanego. Zazwyczaj zgrzeina powstaje w stanie stałym w temperaturze poniżej temperatury topnienia. Jest to wynikiem specyfiki procesu tj. topienia materiału i jednoczesnego wyciskania uplastycznionego materiału na zewnątrz zgrzeiny (złącza) w wyniku działania stałej siły docisku. Zgrzeina przybiera wygląd jak na rysunku 1, gdzie widoczna jest tzw. zgrzeina pierścieniowa. Jednocześnie brak jest poprawnego zgrzania (przetopienia) w centralnej części zgrzeiny.

Obliczenia prowadzono dla prętów aluminiowych serii Al 5182 o temperaturze solidus $-577^{\circ} \mathrm{C}$ i liquidus $-638^{\circ} \mathrm{C}$.

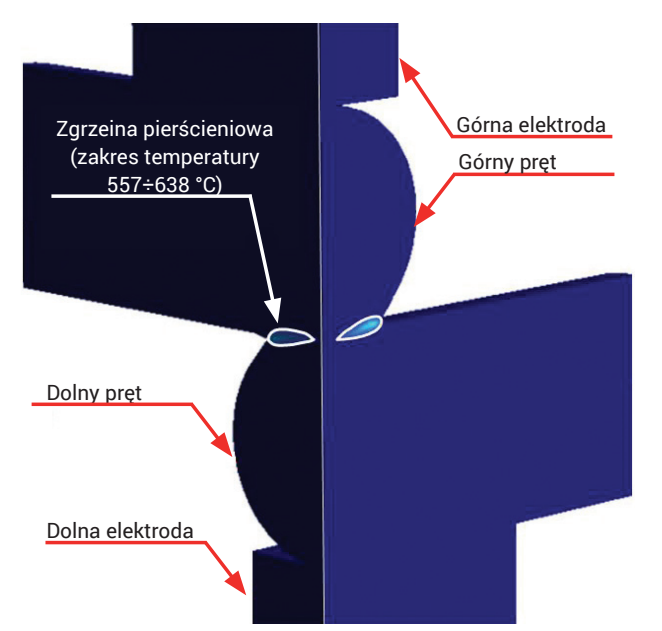

Rys. 1. Rozkład temperatury w obszarze zgrzewania. Zgrzewania prętów na krzyż (docisk pneumatyczny, model 3D)

Fig. 1. Temperature distribution in the welding area. Cross wire welding (pneumatic operating force system, 3D model) 

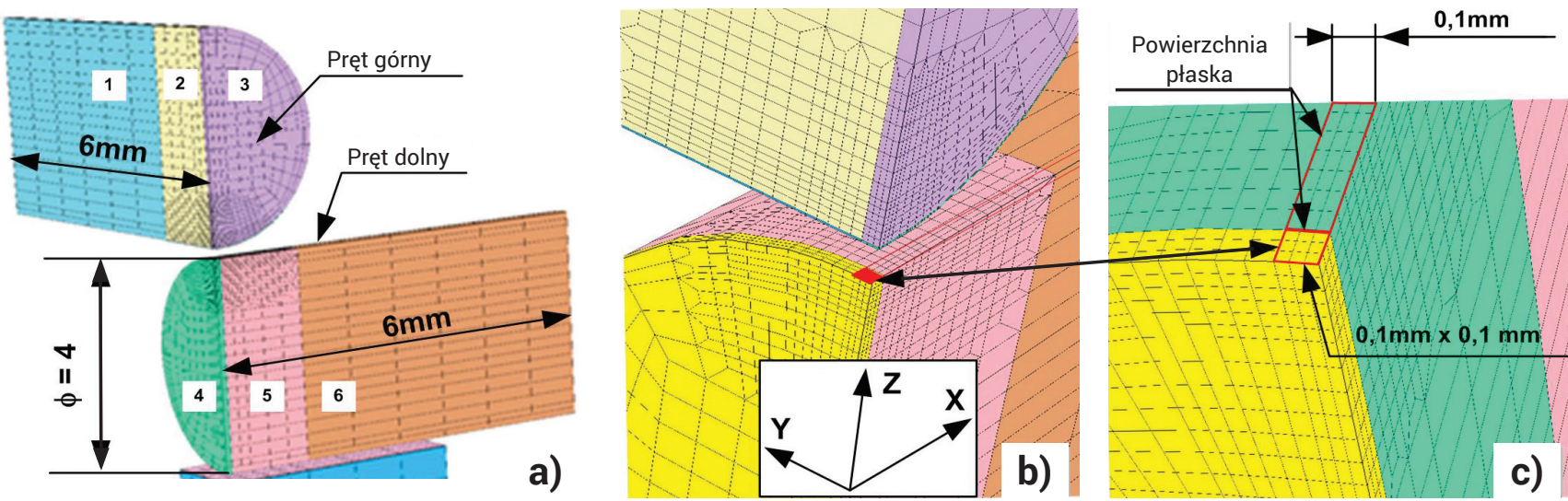

Rys. 2. Geometria modelu 3D zgrzewania prętów aluminiowych (AA 5182) na krzyż: a) wymiary zgrzewanych prętów (usytuowanych prostopadle), b) siatka modelu MES w miejscu styku elementów zgrzewanych, c) powiększona siatka modelu MES

Fig. 2. Geometry of the 3D model of aluminium cross wire welding (AA 5182): a) dimensions of welded elements, b) mesh of MES model at the contact of welded elements, c) magnified mesh in the contact

\section{Model obliczeniowy}

Model 3D do obliczeń MES procesu zgrzewania rezystancyjnego garbowego prętów na krzyż przedstawiono na rysunku 2. Przyjęto następujące założenia do modelu: elektrody miedziane (A2/2), materiał zgrzewany - pręty aluminiowe gatunku AA5182 [13] o średnicy $\varnothing=4,0 \mathrm{~mm}$, długość prętów I = 6,0 mm (rys. 2a). Model 3D składał się z 13600 nodów (węzłów siatki) i 11700 elementów. Dla zapewnienia dokładności obliczeń zagęszczono siatkę w miejscu styku prętów (rys. 2b i 2c). Ponadto dla zapewnienia odpowiedniego kontaktu na początku zgrzewania, pręty w środkowej strefie (na całej długości) były płaskie. Szerokość płaskiej części na rysunku 2 wynosiła 0,1 mm. Oznaczało to, że z uwagi na prowadzenie obliczeń symetrycznych względem płaszczyzny X-Z oraz Y-Z (rzeczywista) powierzchnia kontaktu pomiędzy elementami zgrzewanymi (prętami) na początku zgrzewania miała wymiary 0,2 x 0,2 $\mathrm{mm}$.

W modelu obliczeniowym, celem skrócenia czasu obliczeń, każdy z prętów jest złożeniem trzech niezależnych elementów o różnej gęstości siatki (rys. 2: element 1, 2, 3 - pręt górny; 4, 5, 6 - pręt dolny). Dla przejrzystości każdy z elementów modelu oznaczono innym kolorem.

Analizowano system pneumatycznego i serwomechnicznego docisku elektrod. Przyjęte warunki i wartości graniczne do obliczeń były następujące:

- nominalna średnica jądra - 1,9 mm,

- głębokość przenikania prętów - max. 20\% grubości elementów zgrzewanych (tj. dwóch średnic prętów, $\Delta \mathrm{l}=1,6 \mathrm{~mm}$ ),

- brak wyprysku (Sorpas [13]),

- maksymalny czas przepływu prądu głównego 63 ms (3 ms up-slope + 60 ms czas główny) [14],

- brak wyraźnej deformacji (ugięcia) prętów [15].

\section{Parametry zgrzewania}

Parametry zgrzewania:

- natężenie prądu i = 8 / 9 / 10 / 11/ 12 kA;

- czas przepływu prądu, czas narastania prądu (up-slope) $3 \mathrm{~ms}$ i główny czas zgrzewania $\mathrm{t}=60 \mathrm{~ms}$ ) przyjęto na podstawie danych literatury $[14 \div 16]$;

- siła docisku $F=1,5 / 1,25 / 1,0 / 0,75$ / 0,5 kN dla systemu pneumatycznego docisku;

- sterowanie ruchem elektrody dla systemu serwomechanicznego.
Pozostałe parametry zgrzewania: czas docisku wstępnego - 10 ms, czas docisku końcowego - 100 ms, zgrzewarka inwertorowa DC (1 kHz).

Analiza procesu zgrzewania przeprowadzona dla systemu pneumatycznego docisku miała na celu przebadanie i zobrazowanie przebiegu zmienności parametrów wynikowych procesu oraz określenie, jeśli to możliwe, najkorzystniejszych warunków zgrzewania. Uzyskane wyniki ujawniły zmienność procesu zgrzewania, szczególnie w zakresie wartości siły docisku 0,75 kN, dla tego przeprowadzono dodatkowe obliczenia w tym obszarze siły docisku tj. dla sąsiednich wartości 0,7 i 0,8 kN. Łącznie proces został przeanalizowany dla 35 różnych kombinacji prądu i siły docisku ( $\mathrm{i}=8,9,10,11,12 \mathrm{kA}$, $\mathrm{F}=1,5 ; 1,25 ; 1,0 ; 0,8 ; 0,75 ; 0,7 ; 0,5 \mathrm{kN})$.

Optymalizację procesu przeprowadzono dla systemu serwomechnicznego docisku dla niższych wartości prądów analizowanych w systemie pneumatycznym (8 / 9 / 10 / 11 / 12 kA). Obliczenia numeryczne były prowadzone aż do wystąpienia jednego z przyjętych warunków granicznych.

\section{Obliczenia numeryczne dla systemu pneumatycznego}

Wyniki obliczeń numerycznych dla systemu pneumatycznego docisku przedstawiono na rysunku 3 oraz w tablicy I.

Zebrane wyniki obliczeń numerycznych przedstawione zostały na wykresach przestrzennych, do opracowania których wykorzystano oprogramowanie Statistica [17]. Na rysunku 3 przedstawiono w postaci wykresu powierzchniowego kształtowanie się średnicy jądra zgrzeiny (rys. 3a), czasu przepływu prądu - rysunek 3b, głębokości przenikania prętów (przemieszczenie elektrod - rys. 3c) i energii dostarczonej w czasie zgrzewania (rys. 3d). Zależności przedstawiono $w$ funkcji różnych wartości prądu zgrzewania $(8 \div 12 \mathrm{kA})$ i siły docisku elektrod $(0,5 \div 1,5 \mathrm{kN})$.

Uzupełnieniem wykresów wielkości charakterystycznych przedstawionych na rysunku 3 są ich wartości liczbowe zamieszczone w tablicy I 1c/1d, która zawiera informacje o:

- osiągniętym warunku granicznym (tabl. I 1c) tj.:

- $\mathrm{t}_{\mathrm{z}}$ - maksymalny czas zgrzewania (przepływu prądu, $63 \mathrm{~ms})$,

- P - maksymalne przemieszczenie elektrod (1,6 mm, 
$20 \%$ grubości prętów),

- W - wyprysk,

- charakterze zgrzeiny (tablica I 1d) tj.:

- L - średnica jądra poniżej 0,7 mm (D $\leq 0,7 \mathrm{~mm})$

(D - średnica jadra),

- $P$ - jądro pierścieniowe 0,7 $\mathrm{mm}<\mathrm{D} \leq 1,5 \mathrm{~mm}$,

- F - jądro pełne $(1,90 \mathrm{~mm}<\mathrm{D})$.

\section{Analiza wyników dla system pneumatycznego}

Wyniki przedstawione w tablicy I są uzupełnieniem informacji o parametrach charakterystycznych z rysunku 3.

Wnioski z analizy wyników zamieszczonych na rysunku 3 i w tablicy I są następujące:

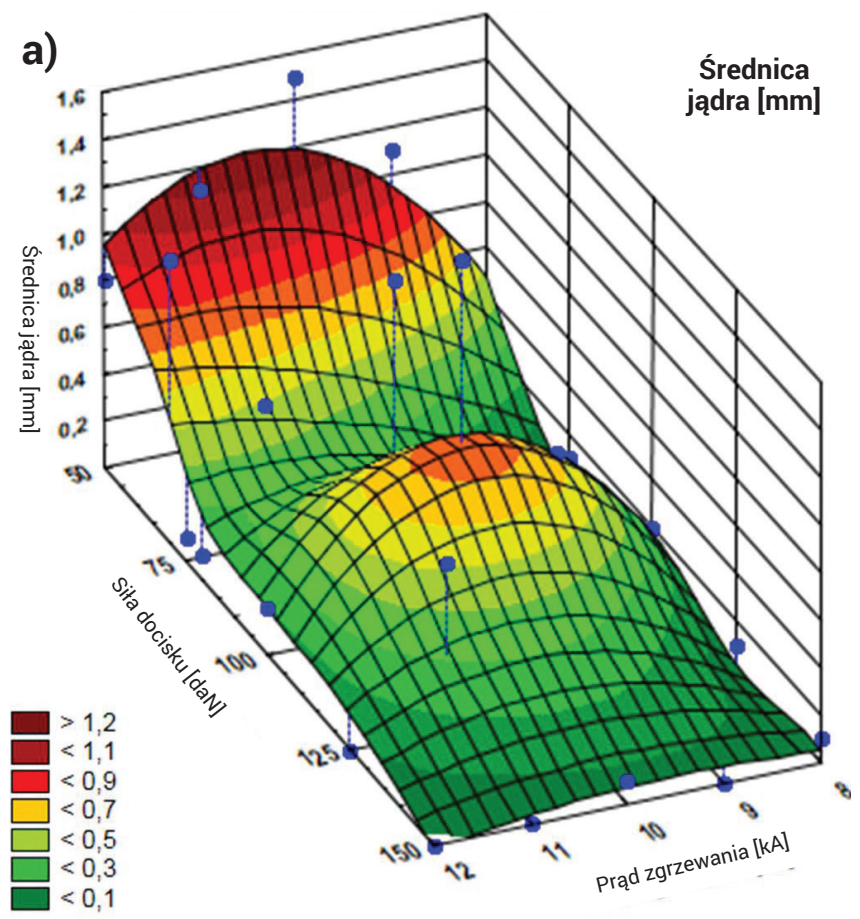

C)

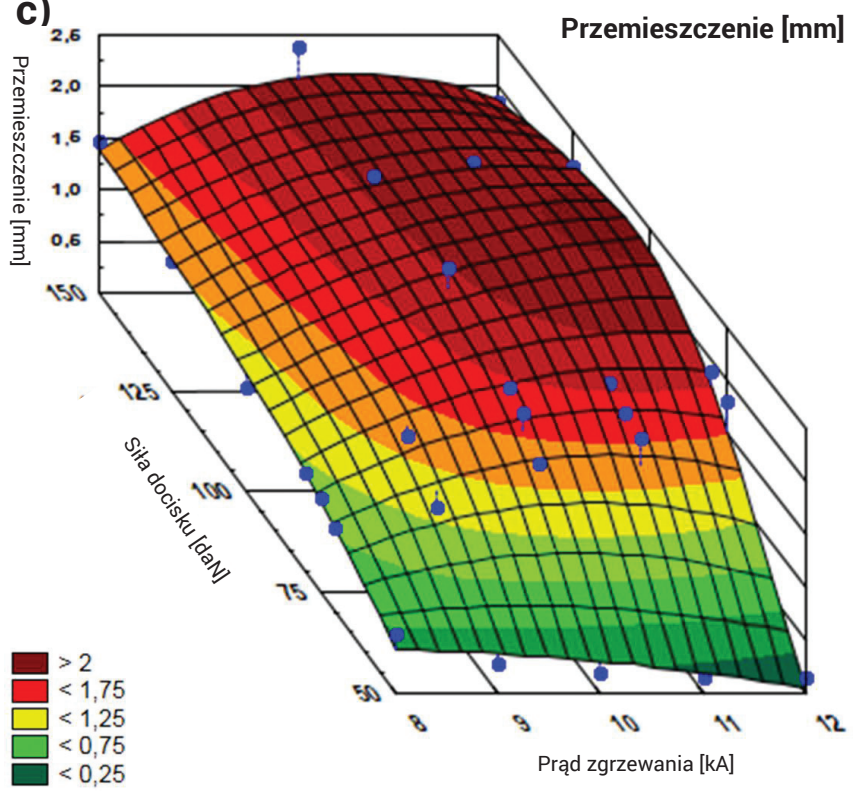

- maksymalna możliwa do uzyskania średnica jądra to 1,5 mm (tabl. I 1a - pole parametrów 1);

- ponadnormatywne przenikanie prętów, powyżej dopuszczalnej wartości, uzyskiwane jest dla mniejszych wartości prądu zgrzewania i wyższych wartości siły docisku (tabl. I 1b - pole parametrów 2, przenikanie końcowe tabl. I 1c - pole parametrów 3b);

- kryterium przekroczenia maksymalnego czasu przepływy prądu zgrzewania (63 ms) obserwowane jest dla mniejszych wartości prądu zgrzewania (tabl. I 1c - pole parametrów 3a);

- w całym zakresie zmienności parametrów prądu zgrzewania i siły docisku, uzyskiwane jest pierścieniowe jądro zgrzeiny (tabl. I 1d - pole parametrów 4);

- zagrożenie wystąpienia ekspulsji obserwowane jest dla najniższy wartości siły docisku i wyższych prądów zgrzewania (tabl. I 1c - pole parametrów 3c).

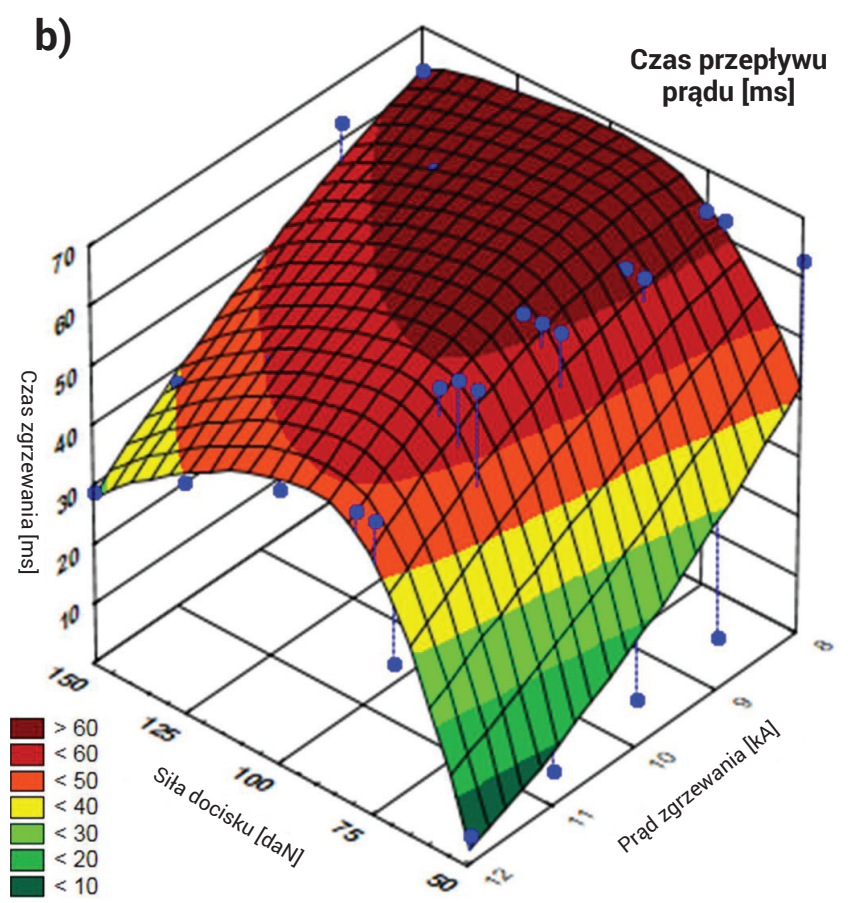

d)

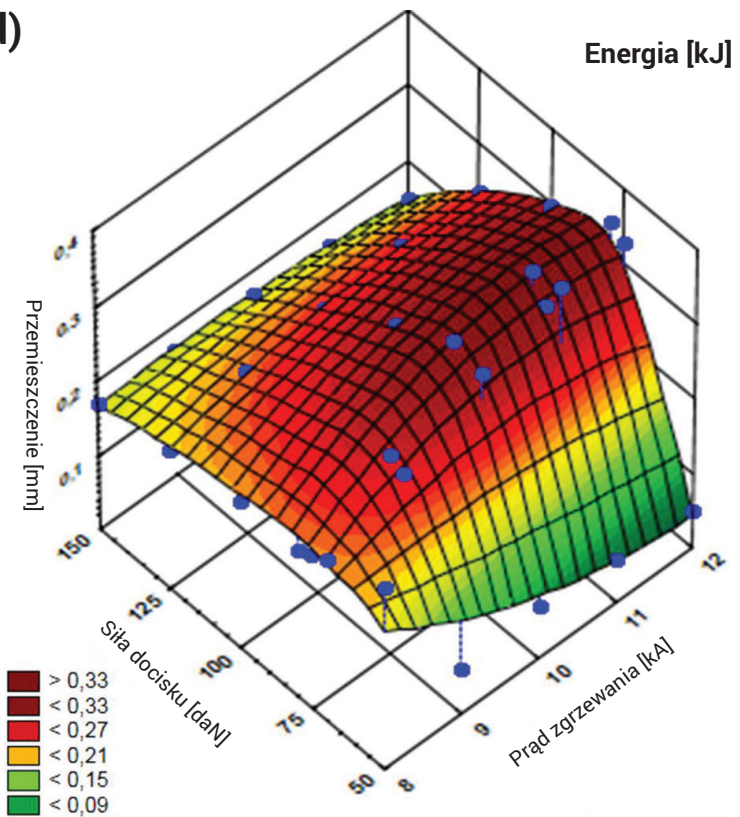

Rys. 3. Przebieg zmienności charakterystycznych wielkości dla pneumatycznego systemu docisku (Al 5182, $\varnothing=4 \mathrm{~mm}$ ) SORPAS [13]: a) średnica jądra zgrzeiny, b) czas przepływu prądu, c) przemieszczenie elektrod (przenikania prętów), d) energia dostarczona do zgrzeiny Fig. 3. Variable characteristic curve for pneumatic operating force system (Al 5182, $\varnothing=4 \mathrm{~mm}$ ) SORPAS [13]:

a) weld nugget diameter, b) welding current flow time, c) travel of electrode (penetration of wires), d) energy supplied to the weld 
Tablica I. Wyniki obliczeń MES zgrzewania prętów na krzyż (AL5182) Table I. Results of MES calculation of cross wires welding (AL5182)

\begin{tabular}{|c|c|c|c|c|c|c|c|c|}
\hline \multirow{4}{*}{\begin{tabular}{|c|} 
prąd \\
zgrzewania \\
{$[\mathrm{kA}]$}
\end{tabular}} & \multicolumn{6}{|c|}{ 1a) średnica jądra zgrzeiny $w[\mathrm{~mm}]$} & 1 & 5 \\
\hline & \multicolumn{6}{|c|}{$0.5 \mathrm{~mm}<\mathrm{D}$ (śred.) $<1.5 \mathrm{~mm}$} & & \\
\hline & \multicolumn{6}{|c|}{ siła docisku } & & $t$ \\
\hline & 1.50 & 1.25 & 1.00 & 0.80 & 0.75 & 0.70 & 0.50 & serwo \\
\hline 8 & 0,1 & 0,1 & 0,2 & 0,0 & 0,1 & 0,0 & 0,3 & 1,95 \\
\hline 9 & 0,0 & 0,0 & 0,6 & 0.0 & 0,0 & 0.0 & 1,1 & 2,00 \\
\hline 10 & 0,1 & 0,1 & 1,5 & 1,1 & 0,1 & 0,0 & 1,5 & 2,20 \\
\hline 11 & 0,0 & 0,7 & 0,3 & 0,0 & 0,2 & 0,5 & 1,1 & \\
\hline 12 & 0,0 & 0,0 & 0,2 & 0,1 & 0,1 & 1,2 & 0,8 & \\
\hline \multirow{4}{*}{$\begin{array}{c}\text { prąd } \\
\text { zgrzewania } \\
{[\mathrm{kA}]}\end{array}$} & \multicolumn{6}{|c|}{ b) Przemiszczenie końcowe [mm] } & 2 & 6 \\
\hline & \multicolumn{3}{|c|}{$\mathrm{P}($ przem. $)<1.6 \mathrm{~mm}$} & \multicolumn{4}{|c|}{$P($ przem.) $>1.6 \mathrm{mph}$} & \\
\hline & \multicolumn{7}{|c|}{ siła docisku } & 17 \\
\hline & 1.50 & 1.25 & 1.00 & 0.80 & 0.75 & 0.70 & 0.50 & serwo \\
\hline 8 & 1.47 & 1.25 & 1,00 & 0,95 & 0.9 & 0,80 & 0,57 & 0,60 \\
\hline 9 & 1,60 & 1,62 & 1,50 & 1,30 & 1,10 & 1,00 & 0,28 & 1,20 \\
\hline 10 & 2,38 & 2,07 & 2,13 & 1,75 & 1,70 & 1,40 & 0,19 & 1,50 \\
\hline 11 & 2,00 & 2,20 & 1,90 & 1,80 & 1,70 & 1,65 & 0,16 & \\
\hline 12 & 1,85 & 2,15 & 2,54 & 1,90 & 0,80 & 0,70 & 0,15 & \\
\hline \multirow{4}{*}{$\begin{array}{c}\text { prąd } \\
\text { zgrzewania }\end{array}$} & \multicolumn{6}{|c|}{ 1c) osiągnięte kryterium } & $3 \mathbf{a}$ & $f$ \\
\hline & \multirow{2}{*}{\multicolumn{2}{|c|}{$P($ przem. $)>(1.6 m$}} & \multirow{2}{*}{\multicolumn{4}{|c|}{$\begin{array}{c}\mathrm{t}_{\mathrm{z}} \text {-czas zgrzewania (63ms) } \\
\text { siła docisku }\end{array}$}} & ysk & \\
\hline & & & & & & & & $\downarrow$ \\
\hline & 1.50 & 1.25 & 1.00 & 0.80 & 0.75 & 0.7 & 0.50 & serwo \\
\hline 81 & $\mathrm{t}_{\mathrm{z}}$ & $t_{z}$ & $t_{z}$ & $t_{z}$ & $t_{z}$ & $t_{z}$ & $t_{z}$ & OK \\
\hline 9 & $t_{z}$ & $\mathrm{t}_{\mathrm{z}}$ & $t_{z}$ & $t_{z}$ & $t_{z}$ & $t_{z}$ & W & OK \\
\hline 10 & $P$ & $P$ & $P$ & $\mathrm{t}_{\mathrm{z}}$ & $t_{z}$ & $t_{z}$ & $\bar{w}$ & OK \\
\hline 11 & $P$ & $P$ & $P$ & $P$ & $t_{z}$ & $t_{z}$ & $\mathrm{~W}$ & \\
\hline 12 & $P$ & $P$ & $P$ & $P$ & $P$ & w & $\bar{w}$ & $3 c$ \\
\hline \multirow{4}{*}{$\begin{array}{c}\text { prąd } \\
\text { zgrzewania } \\
{[\mathrm{kA}]}\end{array}$} & \multicolumn{6}{|c|}{ charakter (rodzaj) jądra [mm] } & 4 & 8 \\
\hline & \multicolumn{2}{|c|}{ F - pelne jądro } & \multicolumn{2}{|c|}{$\mathrm{P}$-jądro pierśc. } & \multicolumn{3}{|c|}{ L-jądro ( $\phi<0.7 \mathrm{~mm})$} & $T$ \\
\hline & \multicolumn{6}{|c|}{ siła docisku } & & $\downarrow$ \\
\hline & 1.50 & 1.25 & 1.00 & 0.80 & 0.75 & 0.70 & 0.50 & serwo \\
\hline 8 & L & L & L & L & L & L & L & $\mathrm{F}$ \\
\hline 9 & L & $\mathrm{L}$ & $\mathrm{L}$ & L & L & $\mathrm{L}$ & $P$ & $\mathbf{F}$ \\
\hline 10 & $\mathrm{~L}$ & $\mathrm{~L}$ & P & $\mathrm{P}$ & $\mathrm{L}$ & $\mathrm{L}$ & $\mathrm{P}$ & $F$ \\
\hline 11 & $\underline{L}$ & $\mathrm{~L}$ & $\mathrm{~L}$ & $\mathrm{~L}$ & $\mathrm{~L}$ & $\mathrm{~L}$ & $\mathrm{P}$ & \\
\hline 12 & $\mathrm{~L}$ & $\mathrm{~L}$ & $\bar{L}$ & L & $\mathrm{L}$ & P & $\mathrm{P}$ & \\
\hline
\end{tabular}

Najistotniejszą informacją jest jednak brak uzyskania głównego wymaganego warunku granicznego, jakim jest nominalna średnica jądra zgrzeiny, która została ustalona na poziomie 1,9 mm i dodatkowo brak pełnego przetopienia jadra zgrzeiny.
Dla porównania w tablicy I przedstawiono wyniki uzyskane dla serwomechanicznego systemu docisku elektrod (kolor zielony). Średnica jądra zgrzeiny jest wyższa niż zakładana (D > 1,9 mm, tabl. I 1a - pole parametrów 5), przemieszczenie elektrod jest niższe od zakładanego $(\Delta \mathrm{I}<1,6 \mathrm{~mm}$, tabl. I 1b - pole parametrów 6), żadne z niepożądanych kryteriów granicznych nie zostało osiągnięte (tabl. I 1c - pole parametrów 7) i uzyskano pełne jądro zgrzeiny (tabl. I 1d - pole parametrów 8).

Porównanie wyników obliczeń MES, w postaci rozkładu temperatury, dla dwóch systemów docisku tj. pneumatycznego i serwomechanicznego oraz różnych wartości prądu zgrzewania przedstawiono na rysunku 4.

Dla systemu pneumatycznego docisku i prądu zgrzewania o wartości $8 \mathrm{kA}$ przedstawiono rozkład temperatury w pełnym zakresie analizowanej temperatury tj. od temperatury otoczenia do temperatury topnienia (liquidus) (rys. 4a). W takim ujęciu nie jest zauważalne, kiedy następuje stapianie materiału. Średnica jądra zgrzeiny obliczana przez oprogramowanie SOPRPAS wskazuje na niewielkie wartości, zaledwie 0,2 mm. Dla takich parametrów zgrzewania nie następuje stapianie materiału.

Dla lepszego zobrazowania przebiegu procesu zgrzewania dla systemu pneumatycznego docisku, z uwagi na małą objętość roztopionego materiału elementów zgrzewanych i związane z tym małe średnice jądra zgrzeiny, przeanalizowano proces w zakresie temperatury solidus $\left(577^{\circ} \mathrm{C}\right)$, liquidus $\left(638{ }^{\circ} \mathrm{C}\right)$. W takim układzie wyraźnie widoczny jest obszar oraz czas stapiania materiału (rys. $4 \mathrm{~b}-4 \mathrm{~ms}$, kolumna 3 ). W pozostałych chwilach nie jest obserwowane stapianie materiału (rys. 4b, kolumna: 1,2 i 4\%9).

Dla systemu pneumatycznego, w wyniku uplastycznienia obszaru zgrzewania i działania stałej siły docisku, stopiony materiał jest wypychany na zewnątrz. Tworzy się coraz to większa powierzchnia kontaktu materiałów zgrzewanych (prętów), co powoduje gwałtowny spadek gęstości prądu, czego efektem jest natychmiastowe ochładzanie materiału zgrzeiny, również w bardzo krótkim czasie, jednej milisekundy (rys. 4b-5 ms, kolumna 4). Również wyłączenie prądu zgrzewania, dla analizowanego przypadku zgrzewania prętów

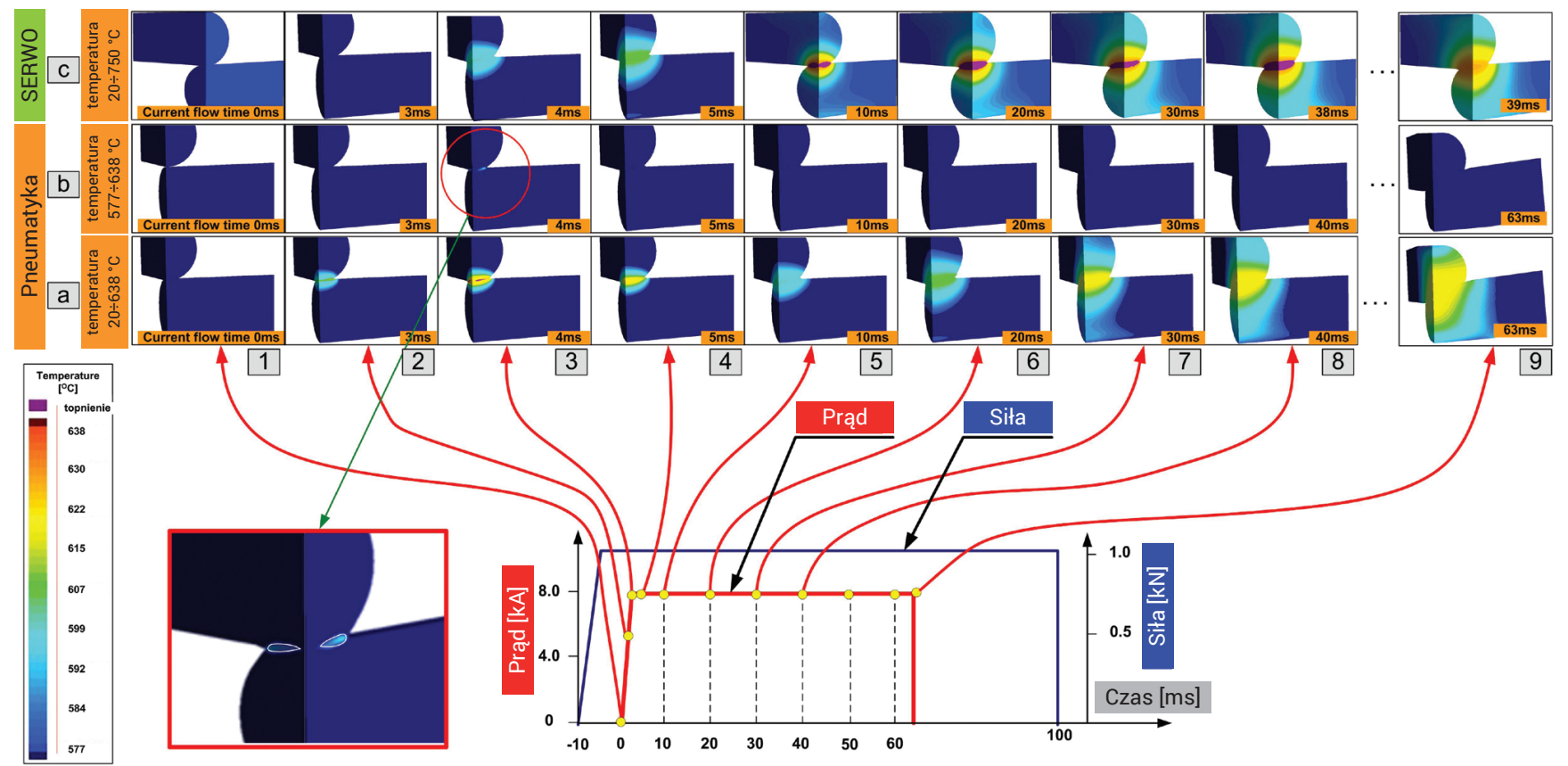

Rys. 4. Rozkład temperatury $w$ obszarze zgrzewania dla systemu docisku: $a)$ pneumatycznego $(i=8 \mathrm{kA}, \mathrm{F}=1,0 \mathrm{kN})$, b) pneumatycznego $(i=10 \mathrm{kA}, \mathrm{F}=1,0 \mathrm{kN}), \mathrm{c})$ serwomechnicznego $(\mathrm{i}=8,0 \mathrm{kA})$

Fig. 4. Temperature distribution in the welding area for the operating force system: a) pneumatic $(i=8 \mathrm{kA}, F=1.0 \mathrm{kN}), \mathrm{b})$ pneumatic $(i=10 \mathrm{kA}$, $\mathrm{F}=1.0 \mathrm{kN}), \mathrm{c})$ servomechanical $(\mathrm{i}=8.0 \mathrm{kA})$ 
aluminiowych (Al 5182), powoduje natychmiastowe (w przeciągu $1 \mathrm{~ms}$ ) obniżenie temperatury poniżej temperatury topnienia (rys. 4c - $39 \mathrm{~ms}$, kolumna 9).

Dla porównania na rysunku 4c przedstawiono rozkład temperatury dla systemu serwomechnicznego i wartości prądu zgrzewania 8 kA tj., takiej wartości, dla której dla systemu pneumatycznego docisku w ogóle nie następuje stapianie materiału (rys. 4a). Z uwagi na odmienny sposób sterowania ruchem elektrod, obserwowane jest wyraźne stapianie materiału zgrzewanego i tworzenie pełnego jądra zgrzeiny. Czas zgrzewania ulega również zdecydowanemu skróceniu. Maksymalna temperatura w obszarze zgrzewania wynosi $601^{\circ} \mathrm{C}, 631^{\circ} \mathrm{C}$ i $752^{\circ} \mathrm{C}$ odpowiednio dla przypadku a, b i c - rys. 4.

\section{Optymalizacja procesu}

Nowy zaproponowany sposób sterowania z zastosowaniem systemu serwomechanicznego polega na pracy przy mniejszej wartości siły docisku na początku zgrzewania (przepływu prądu) i spowolnieniu ruchu elektrody w czasie jego przepływu. To powoduje mniejszy docisk elektrod na materiały zgrzewane (pręty), mniejsza jest powierzchnia kontaktu elementów zgrzewanych i tym samym większa jest rezystancja obszaru zgrzewania (rys. 5a). W wyniku przepływu prądu (o stałej wartości - stabilizacja prądu) przez obszary o wyższej rezystancji wydzielana jest wyższa moc (rys. 5b). Materiał zgrzewany jest intensywniej nagrzewany i w efekcie stapiany. Z kolei materiał bliski temperaturze topnienia ma wyższą rezystancję, co powoduje lawinowy efekt nagrzewania i w efekcie topienia materiałów zgrzewanych.
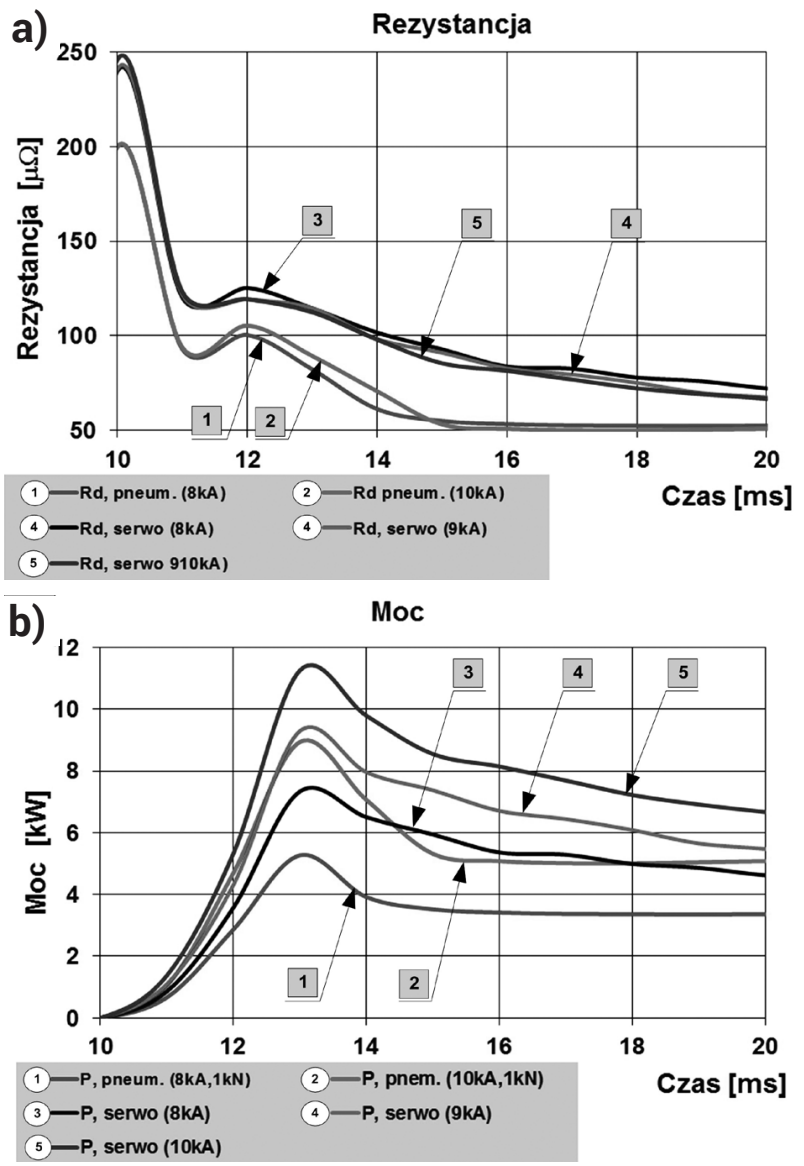

Rys. 5. Przebiegi rezystancji obszaru zgrzewania i mocy chwilowej (na początku przepływu prądu zgrzewania) dla systemu: 1,2) pneumatycznego; $3 \div 5$ ) serwomechnicznego docisku

Fig. 5. Waveforms of welding area dynamic resistance and instantaneous power (at the beginning of the welding current flow) for the: 1,2 ) pneumatic; $3 \div 5$ ) servomechanical operating force system
Optymalizację procesu zgrzewania przeprowadzono porównując przebiegi charakterystycznych wielości (przemieszczenia elektrod, mocy chwilowej i średnicy jądra) dla dwóch systemów docisku elektrod, pneumatycznego i serwomechnicznego - rysunek 6. Dla lepszego zobrazowania porównanie przeprowadzono dla tej samej wartości prądu zgrzewania $8 \mathrm{kA}$. Dla tej wartości prądu, dla systemu pneumatycznego docisku, nie jest możliwe uzyskanie poprawnego połączenia. Mało widoczny, wręcz niezauważalny, jest efekt topienia materiału zgrzewanego (rys. 4a). Natomiast dla systemu serwomechnicznego uzyskiwane jest pełne jądro o założonej średnicy większej od 1,9 mm (rys. 4c i rys. 6c).
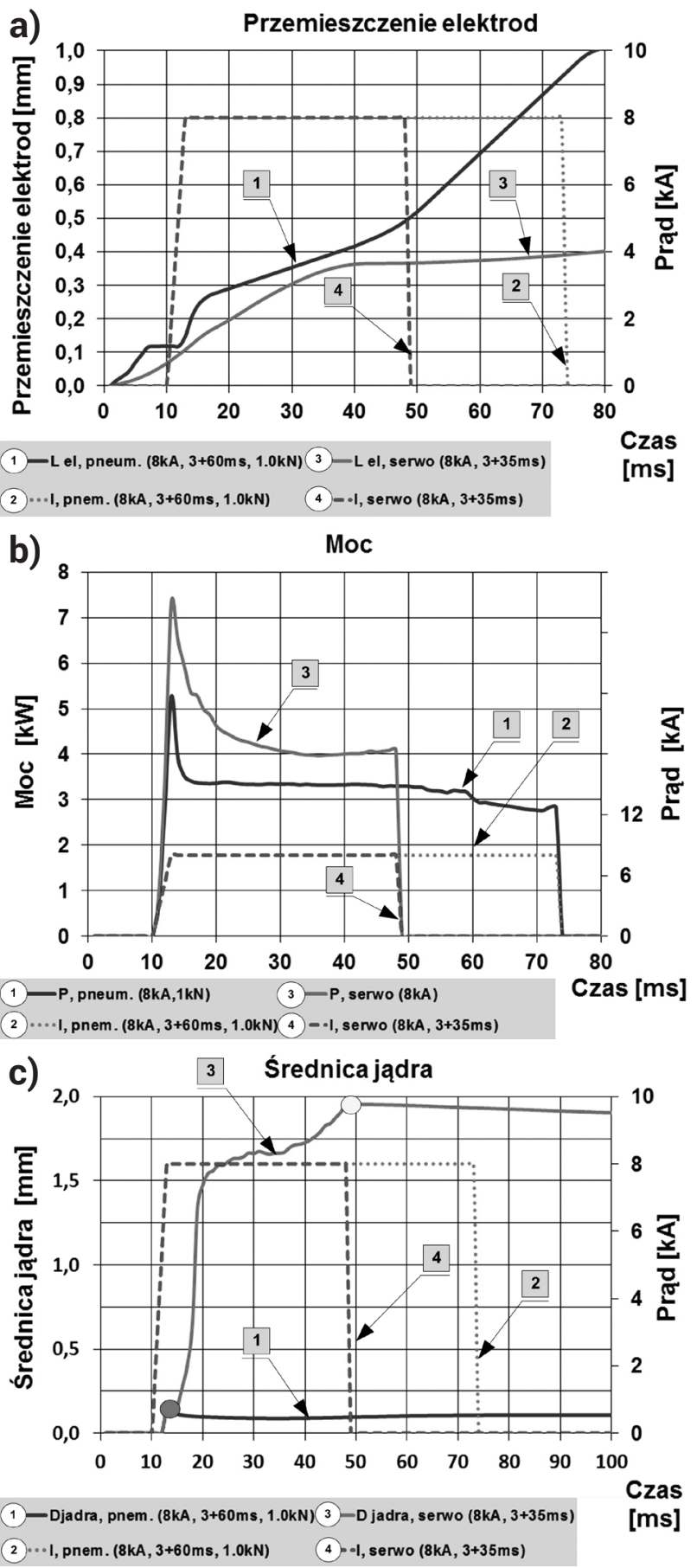

Rys. 6. Wyniki obliczeń MES: a) przemieszczenie elektrod (głębokość przenikania prętów), b) moc chwilowa, c) średnica zgrzeiny: krzywa 1,2 - docisk pneumatyczny ( $\mathrm{i}=8,0 \mathrm{kA}, \mathrm{P}=1,0 \mathrm{kN})$, krzywa 3 , 4 - docisk serwo ( $i=8,0 \mathrm{kA}$, serwo)

Fig. 6. FEM calculations results: a) travel of electrode (penetration of wires), b) instantaneous power, c) weld diameter. curve 1, 2 -pneumatic force system $(i=8.0 \mathrm{kA}, P=1.0 \mathrm{kN})$, curve 3,4 - servo force system ( $i=8.0 \mathrm{kA}$, servo) 
Krzywe o numerach 1 i 2 z rysunku 6 odnoszą się do systemu pneumatycznego natomiast krzywe 3 i 4 do systemu serwomechnicznego. Krzywe 2 i 4 przedstawiają przebieg prądu zgrzewania a krzywe 1 i 3 przemieszczenie elektrod (rys. 6a), przebieg mocy (rys. 6b) i średnicę jądra (rys. 6c), odpowiednio dla systemu pneumatycznego i serwomechnicznego.

Przebieg procesu dla systemu pneumatycznego można opisać w następujący sposób. Przy zadanej stałej wartości siły docisku (system pneumatyczny) i przy określonej wartości i czasie przepływu prądu (rys. 6a, krzywa 2) generowana jest określona moc zgrzewania (rys. 6b - krzywa 1) uzyskiwane jest określone przemieszczenie elektrod (rys. 6a, krzywa 1). W wyniku wzajemnego oddziaływania powyższych czynników uzyskiwane jest jądro o kreślonym kształcie i wymiarach (tabl. I 1a, rys. 6c - krzywa 1) wynoszącej zaledwie 0,2 mm.

Zbyt mała wartość prądu zgrzewania powoduje jedynie uplastycznienie materiału, które powoduje nadmierny wzrost powierzchni kontaktu. Gęstość prądu jest zbyt mała i nie jest możliwe topienie materiału zgrzewanego. Materiał zgrzewany w obszarze styku jest jedynie nagrzewany i uplastyczniany. W efekcie końcowym przekroczone zostało kryterium maksymalnego czasu zgrzewania wynoszące $63 \mathrm{~ms}$.

Punktem wyjścia do optymalizacji procesu zgrzewania jest odpowiednia zmiana przebiegu przemieszczenia elektrod tj. głębokość przenikania prętów (rys. 6a, krzywa nr 3), która jest wynikiem zastosowania systemu serwomechnicznego docisku i odpowiedniego sterowania przemieszczeniem elektrod. Istota zmiany przebiegu przemieszczenia polegała na bezpośrednim sterowaniu tego parametru. Sterowanie polegało na spowolnieniu ruchu elektrody (przemieszczenia elektrod), w szczegól- ności na początku przepływu prądu, by uzyskać korzystniejszy rozkład gęstości mocy i wygenerować większą moc zgrzewania (rys. 6b, krzywa 3) w porównaniu do systemu pneumatycznego. Wolniejszy przebieg przemieszczenia elektrod, przy stałym prądzie zgrzewania, skutkuje kolejno: wzrostem rezystancji w obszarze kontaktu, mocy zgrzewania, energii dostarczonej do obszaru zgrzewania (szczególnie w strefie styku pomiędzy materiałami zgrzewanymi). W efekcie uzyskany zostaje korzystniejszy rozkład temperatury w obszarze zgrzewania, który pozwala na uzyskanie nominalnej średnicy zgrzeiny $(1,95 \mathrm{~mm})$, większej o założonej (1,9 mm) (rys. 6c, krzywa 3).

Efektem końcowym takiego sposobu sterowania jest odpowiedni przebieg siły docisku o wartościach mniejszych niż dla systemu pneumatycznego docisku. To właśnie siła docisku ma wpływ na wartość rezystancji, szczególnie w obszarach kontaktowych (szczególnie w konfiguracji: pręt zgrzewany - pręt zgrzewany), a to z kolei wpływa na odpowiedni rozkład przestrzenny mocy zgrzewania. W dalszej kolejności przekłada się to na odpowiedni rozkład temperatury w obszarze zgrzewania i w efekcie końcowym na topienie materiału oraz tworzenie się zgrzeiny o odpowiednio większym rozmiarze.

Podsumowanie tej części analizy, dotyczącej wartości prądu zgrzewania 8,0 kA, uznanej za zbyt małą dla uzyskania poprawnego połączenia $w$ systemie pneumatycznego docisku jest stwierdzenie, że w wyniku zastosowania systemu serwomechanicznego i odpowiedniego sterowania (siły lub/i przemieszczenia) jest możliwa zdecydowana poprawa procesu zgrzewania polegająca na uzyskaniu założonej wartości średnicy zgrzeiny (> 1,9 mm) przy spełnieniu pozostałych wymagań (kryteriów jakości).

\section{Podsumowanie}

Dobór optymalnych parametrów zgrzewania prętów na krzyż, w szczególności dla materiałów o wysokim przewodnictwie cieplnym i elektrycznym takich jak stopy aluminium, dla systemu pneumatycznego docisku jest bardzo trudny, wręcz niemożliwy biorąc pod uwagę wymóg uzyskania pełnego przetopienia jądra zgrzeiny. Ograniczenia wynikają z braku możliwości szybkiego sterowania siły w czasie procesu zgrzewania.

Cechą charakterystyczną systemu pneumatycznego docisku jest to, że parametrem zadanym jest siła (docisku) a parametrem wynikowym jest przemieszczenie (elektrod), które nie jest sterowane.

Sposobem na poprawę przebiegu procesu zgrzewania (rozszerzenie okna parametrów) jest zastosowanie serwomechanicznego systemu docisku elektrod. W trybie pracy z przemieszczeniem elektrod możliwe jest zadawanie korzystniejszej trajektorii ruchu elektrod, która pozwala kolejno na uzyskanie korzystniejszego rozkładu gęstości prądu, korzystniejszego przestrzennego rozkład mocy zgrzewania. To w efekcie końcowym przekłada się na uzyskanie korzystniejszego rozkładu temperatury w obszarze zgrzewania i uzyskanie jądra zgrzeiny o pełnym przetopieniu i większej średnicy.

Zastosowanie systemu serwomechnicznego docisku i sterowanie przemieszczeniem elektrod pozwala ponadto na sterowanie końcowym przemieszczeniem elektrod i uzyskanie określonego (mniejszego) zgniotu końcowego.

Niniejszy artykuł powstał w wyniku realizacji projektu TANG01/267374/NCBR/2015 finansowanego ze środków Narodowego Centrum Badań i Rozwoju (NCBR) i Narodowego Centrum Nauki (NCN) realizowanego w latach 2015-2017.

\section{Literatura}

[1] H. Zhang, J. Senkara: Resitance welding Fundamentals and Applications, Taylor\&Francis Gropu, 2011.

[2] X. Zhang, G. Chen, Y. Zhang, H. Lai: Improvement of resistance spot weldability for dual-phase (DP600) steels using servo gun, Journal of Materials Processing Technology, 2009

[3] H. Tang, W. Hou, S. Hu: Forging force in resistance spot welding. Proceedings of the Institution of Mechanical Engineers, Part B: Journal of Engineering Manufacture, Volume 216, Number 7, 2002.

[4] J. Gould: Joining Aluminum Sheet in the Automotive Industry - A 30 Year History, Welding Journal (Welidng Research) vol 91, January, pp. 23-34, 2012.

[5] X. Q. Zhang, G. L. Chen, Y. S. Zhang: On-line evaluation of electrode wear by servo gun, Int. J. Adv. Manuf. Technol., Vol 36, 2008.

[6] S. A. Slavick: Using Serwoguns for Automated Resistance Welding, Welding Journal vol. 78, No 7, 1999.

[7] Z. Mikno, Z. Bartnik, A. Ambroziak, A. Pietras: Patent P. 401723 Sposób zgrzewania rezystancyjnego garbowego zwłaszcza blach stalowych z wytłoczonymi garbami. Patent P. 401723 (Eng. Method for Projection Resistance Welding of Steel Plates with Embossed Projections), 2012.

[8] Z. Mikno, B. Grzesik, M. Stępień: Patent P. 412615 Sposób zgrzewania rezystancyjnego garbowego w konfiguracji na krzyż zwłaszcza prętów aluminiowych, 2015.
[9] Z. Mikno, Z. Bartnik: Projection welding with pneumatic and servomechanical electrode pressure system in FEM calculation - comparison. The 7th International Seminar on Advances in Resistance Welding 12-14 September, Busan, Korea, 2012.

[10] Z. Mikno: Projection Welding with Pneumatic and Servomechanical Electrode Operating Force Systems, Welding Journal (Welidng Research) vol. 95, August, pp. 286-299, 2016.

[11] Z. Mikno, M. Stępień, B. Grzesik: 2016, Optimization of Resistance Welding by using Electric Servo Actuator. Welding in the World manuscript, Open Access 21 February 2017. DOI:10.1007/s40194-017-0437-x.

[12] Z. Mikno, B. Grzesik. M. Stępień: Cross-Wire Projection Welding of Aluminium Alloys in relation to Pneumatic and Servomechanical Electrode Force Systems, 10th International Conference Tokyo, JAPAN, Trends in Welding Research, October 11-14, 2016.

[13] The database of the material and electrode parameters: model 2D version 11.2 and model 3D Version 4.0x64 of the Swantec Inc. SORPAS Software (http:// swantec.com/)

[14] H. Papkala: Zgrzewanie oporowe metali, Wydawnictwo KaBe Krosno 2003.

[15] RWMA - Resistance Welding Manual, Revised 4th edition.

[16] Projection Welding, Gould, J E, ASM International, ASM Handbook. Vol. 6: WeIding, Brazing, and Soldering (USA), 1993, pp. 230-237, 1993.

[17] Statistica 12 (wersja testowa), www.statsoft.pl. 